\title{
Who Says Shut Up and Dribble? \\ Race and the Response to Athletes' Political Activism
}

\author{
David Niven \\ University of Cincinnati \\ Department of Political Science \\ David.Niven@uc.edu
}

\begin{abstract}
In response to a political comment from NBA superstar LeBron James, a Fox News commentator suggested he "shut up and dribble." James and many others considered the comment racist. Defenders suggested it was driven by political ideology rather than race. Interestingly, both perspectives could find support in existing research, as some studies depict race as a central factor in responses to political athletes, while other studies dismiss the role of race and find that political ideology and nationalistic sentiments drive how people see activist athletes. Using responses to a large national survey asking whether respondents find athlete political activism "acceptable," here I find strong evidence that both ideology and race shape attitudes on the subject. The picture that emerges reveals that party and ideology matter, but even after controlling for them, the race and racial views of the respondent help shape their perspective on political athletes. Establishing the importance of race and racial views here helps illuminate why the intersection of sports and politics generates such fierce responses including unvarnished vitriol from some political figures.
\end{abstract}

PREPARED FOR PRESENTATION AT THE ANNUAL MEETING

OF THE AMERICAN POLITICAL SCIENCE ASSOCIATION

SEPTEMBER 10, 2020 
Do racial views shape the responses of Americans to athlete political activism? While the media's discussion and debate on political athletes typically elides race in favor of the language and imagery of patriotism (Graber, Figueroa, and Vasudevan 2019), there is an emerging body of work which finds race and racial views closely connected to feelings toward sports-related controversies (for example, Wallstein, Nteta, McCarthy and Tarsi 2017; Stratmoen, Lawless, and Saucier 2019). Quantifying the degree to which race contributes to perceptions of political athletes offers an opportunity to better understand the nature of the intersection of sports and politics in our culture, to recognize the dilemma athletes face when deciding how or whether to become politically visible, and to more realistically account for the behavior of political figures who have demonized the political athlete.

\section{Sports and Politics and Race}

The prominence of the intersection of sports and politics in recent years owes much to the leadership of LeBron James. James, considered among the greatest basketball players in the history of the game and perhaps the world's most prominent athlete, has over the course of his career become progressively more politically active (Coombs and Cassilo 2017). James has repeatedly used his position to draw attention to violence and poverty and racism, and taken extraordinary actions to give life to words, even personally creating and funding a unique public school in his hometown of Akron, Ohio that offers comprehensive social services for students and their families.

James has been outspoken in his criticism of Donald Trump. After an interviewer asked him about Trump in February 2018, a Fox News commentator said on her show that she was not interested in hearing from someone paid to "bounce a ball" and that James should "shut up and dribble." In defense against the charge that her comment 
was racist, the host cited numerous instances in which she had suggested that other people "shut up." Two years later, however, when New Orleans Saints quarterback Drew Brees spoke out to criticize those who protest during the national anthem, the same Fox Host welcomed Brees' comments. The contrasting response to political statements - telling an African American athlete to shut up while praising a white athlete - bolstered the belief of many observers that race lied at the bottom of all this.

Beyond James and the rising political activism of his NBA peers, another catalyst in the rise of sports and politics is the far less storied athlete Colin Kaepernick. Indeed, much of the renewed urgency of politics in sports - or of sports in politics - in recent years can be traced to Kaepernick's initially ill-noticed act of protest against racial injustice. As the National Anthem was played before an NFL exhibition game on August 14, 2016, Kaepernick, then the San Francisco 49ers quarterback, eschewed the customary respectful pose and instead took a knee. No other players joined in his gesture. Not scheduled to play in the game, and therefore not wearing a uniform, Kaepernick's personal protest drew scant attention. Two weeks later, however, fully decked out in his 49ers uniform, Kaepernick took a knee again and the media pounced. Calling it an act of defiance against racial inequality and police brutality (Branch 2018), Kaepernick's anthem protest drew a deluge of media attention and criticism (Johnk 2017). Kaepernick was even called a "traitor" by NFL executives who vowed that he would never play for their teams (Bondy 2016).

Several other African American players joined Kaepernick’s anthem protest during the 2016 season, but participation was not widespread. As the next season began, the threats against Kaepernick's career had proven prophetic. Kaepernick's contract had 
expired and no NFL team signed him. ${ }^{1}$ Still, a smattering of players began the 2017

season by taking a knee or raising a fist during the National Anthem (Branch 2018), largely citing concerns with racial injustice and economic inequality (Flaherty 2017).

The modest size of the anthem protest was transformed in late September 2017, however, when Donald Trump offered his thoughts during a political rally in Alabama for U.S. Senate candidate Roy Moore. Trump asked the crowd, "Wouldn't you love to see one of these NFL owners, when somebody disrespects the flag, to say, 'Get that son of a bitch off the field right now."'

With that broadside against their colleagues and their profession, many players began reexamining their posture toward the anthem protests. Across the league, scores of players publicly objected to Trump's comments and participation in anthem protests soared. By the end of the season, the players had drawn so much attention to their stance and so thoroughly disrupted the politically placid league that the anthem protests were named the biggest sports story of the year by the Associated Press and numerous other media outlets (Branch 2018).

While several white players participated in the anthem protests, African American players comprised the overwhelming majority of the NFL's protesters (Niven 2019), many explaining their participation with direct reference to race. Malcolm Jenkins of the Philadelphia Eagles, for example, said he was protesting because "there's just a lot of things systematically that have been set up in this country since its inception

\footnotetext{
${ }^{1}$ Kaepernick's failure to attract any offers was the subject of litigation, ultimately settled by an undisclosed payment from the league (Belson 2019). Kaepernick teammate and fellow protester Eric Reid also settled a claim against the league based on the modest contract offer he attracted in 2018.
} 
really...that put minorities, especially African Americans, at a disadvantage" (Flaherty 2017).

While Kaepernick's act seemed shocking to some, protesting during the anthem was not without precedent. Two medal-winning U.S. Olympic athletes famously raised a fist during the National Anthem at the 1968 Olympics, and an NBA star refused to stand during the anthem in 1996 (Johnk 2017). ${ }^{2}$ Not long before Kaepernick took a knee, several NFL players had been outspoken on justice and violence issues in other ways (Schmittel and Sanderson 2015), even bringing that commitment to the playing field when members of the then St. Louis Rams took the field with their hands in the air, symbolically protesting the shooting of Michael Brown by a police officer in nearby Ferguson, Missouri (Sanderson, Frederick, and Stocz 2016). In each of these instances, the participants were African American speaking out on matters of race.

While the nature of their activism varied, several of the most prominent political activist athletes in the 1950s, 1960s, and 1970s, including football's Jim Brown, basketball's Bill Russell and Kareem Abdul-Jabbar, and boxing's Muhammad Ali were each African Americans who spoke out on matters of racial injustice (Goudsouzian 2006, 2017; Gorsevski and Butterworth 2017; Linden 2016). It is fair to say that issues

\footnotetext{
${ }^{2}$ A similar, if quieter, protest effort was conducted by Toronto Blue Jays player Carlos Delgado, a native of Puerto Rico (Elias 2011). While playing road games in 2004, Delgado stayed in the dugout when his teammates were summoned to the field in stadiums playing "God Bless America" during the $7^{\text {th }}$ inning stretch. Delgado sat to protest the wars in Iraq and Afghanistan. Though there was certainly media coverage of Delgado's quiet protest, several factors including the fact his act of defiance took place in the dugout rather than on the field and and that he played for a Canadian team, meant Delgado did not face nearly the deluge of attention that Kaepernick would endure 12 years later.
} 
of race have been and remain at the center of the political athlete's activism (see, for example, Cooper, Macaulay, and Rodriguez 2019).

Beyond inspiring activism, race plays a central role in the general outlook of players and coaches. Interviews with African American college athletes revealed the centrality of race and racial issues to their lives and their beliefs (Agyemang, Singer, and DeLorme 2010). Meanwhile, a survey of collegiate coaches found race powerfully influenced their level of tolerance for activism and protest activity (Druckman, Howat, and Rothschild 2019). African American coaches were more likely than white coaches to express support for athletes engaging in various forms of protest including kneeling during the anthem. African Americans were more likely than white coaches to oppose team rules that could inhibit political activity, and more likely to believe that player political activity reflects genuine concern rather than attention seeking or conformity to peers.

This is by no means to suggest there are no white activist athletes or athletes expressing concerns about issues having little to do with race. And clearly the world of sports can be employed to advance white perspectives (for example, Kusz 2007). Nonetheless, the history of sports and politics both now and for the last several decades demonstrates that the most prominent political acts by the most prominent athletes have come from African Americans concerned about issues of race.

\section{The Public's View of Sports and Politics}

The matter of whether racial views shape people's response to sports and politics has been examined from a wide array of angles and produced conflicting sets of findings. 
On the one hand, race and racial views have been linked to the response to individual athletes such as Colin Kaepernick. Towler, Crawford and Bennett (2020) found Kaepernick's activism served as a mobilizing force for African Americans. Intravia and colleagues found responses to a politically-charged Nike ad featuring Kaepernick varied by race (Intravia, Piquero, Piquero, and Byers 2019).

More generally, Lacina (2019) found that several star African American players in the NFL suffered a loss in popularity after the anthem protests - regardless of whether they had personally participated in the protests. The effect was particularly notable among whites with low levels of education. Watanabe and Cunningham (2020), meanwhile, link racial bias to NFL game attendance figures after the protests.

While African Americans were found to be more supportive of the protesting players than whites (Intravia, Piquero, and Piquero 2018), belief-based differences were also found. That is, support for the protesting players is considerably higher among those who believe racial prejudice is an ongoing problem (Stratmoen, Lawless, and Saucier 2019).

Beyond distinctions in approval based on race or racial views, others have found a tendency to inject race into a sports and politics discussion. When four African American NBA stars used a prominent ESPN awards show to speak out about criminal justice, Frederick, Pegoraro, and Sanderson (2018) found the resulting discussion online was highly centered on race. 3

3 On the other hand, a study focused on responses to LeBron James' activism found that people were guided by their feelings toward James rather than any particular issue at hand (Johnson, Reinke, Noble, and Camarillo 2020). 
Several researchers have also found race and racial views to color opinions on whether college athletes should be eligible to be paid (Wallsten, Nteta McCarthy, and Tarsi 2017; Druckman, Howat, and Rodheim 2016). Specifically, whites and those high in racial resentment were more likely to oppose paying college athletes.

Other researchers, however, have suggested that responses to sports and politics are driven by ideology or nationalistic sentiments rather than race.

Sorek and White (2016) find that feelings about football are intertwined with sentiments of national pride among whites. This is not the case among African Americans, for whom the two have little connection. As such, nationalistic sentiments, rather than race itself, may best explain responses to such events as the anthem protests. Similarly, Sevi and colleagues (2019) find that notions of traditionalism and support for authority guide responses to the anthem protests rather than race. Media coverage may feed this dynamic, as one study on the anthem protests found that coverage tended to emphasize a discussion framed around questions of patriotism rather than the underlying racial issues cited by the protesters (Graber, Figueroa, and Vasudevan 2019). Beyond anthem protests, Thorson and Serazio (2018) suggest that conservatives are uncomfortable with any mixture of sports and politics.

When asked open-ended questions about sports and politics, respondents who object tend not to cite race. Serazio and Thorson (2020) found people objected to politics interfering with their enjoyment of sports, and asserted that neither the athletes nor their audiences were sufficiently well informed to justify political activity. These sentiments very similar to the Fox News host saying she did not want to hear from LeBron James because he was paid to "bounce a ball." Chaplin and Montez de Oca (2019) found white college students saw their objections to anthem protests in 
nationalistic terms having nothing to do with race. Indeed, they were collectively baffled by the protests, and saw the players as disrespectful and immature. 4

Beyond notions of political sports figures, the entirety of the sports world has long been depicted as some kind of race-blind model of life. Writing in the 1950s, Charles Bucher (1957), one of the central figures who helped define the role of physical education in our schools, published a scholarly article literally titled, "Sports are colorblind." Without caveat or qualification, Bucher $(1957,21)$ wrote that "Sports have the formula for breaking down racial barriers. They are 'color blind.' On the diamond, gridiron, gymnasium floor, or playfield, a person is respected for his ability to hit home runs, make touchdowns, dunk baskets, or serve tennis aces. Whether spectators are from south, west, north, or east, they cheer, applaud and stamp their feet in praise of the athlete who executes a good play." Bucher $(1957,21)$ quotes a Big Ten football coach triumphantly asserting, "There is no more democratic way of life than what is depicted on the athletic field. There a boy is judged solely on his character, personality, and ability, rather than what his race, color, or religion might be." Those tempted to write off Bucher's utopian depiction of a color-blind world of sports must reckon with the fact that even now, Davis, Thornton, and Moxley-Kelly $(2018,469)$ find in conversations with college students a willingness to assert "that sport is immune to social influences such as race." Even when prompted to account for apparent racial disparities like the paucity of African American quarterbacks, Davis and colleagues found students happily

4 Several NFL players who participated in the anthem protests spoke directly to challenges to their patriotism and love of country. "I love hot dogs, like any other American. I love football, like any other American," said Michael Bennett of the Seattle Seahawks. "But I don't love segregation. I don't love riots. I don't love oppression. I don't love gender slander. And I just want to see people have equality that they deserve" (Flaherty 2017) 
explaining that the position required a certain "fit," and it was the presence or absence of that fit, not race, that determined opportunities to play the position $(2018,465)$.

Available research thus leaves us with two seemingly irreconcilable conclusions. Either the response to sports and politics is about race, or, the response to sports and politics, like the underlying response to sports itself, has nothing to do with race. Rather than standing in stark conflict with each other, could it be the case that these two lines of findings reflect conflicting vantage points rather than conflicting evidence? If you begin by looking for evidence that views of sports and politics are based on race, you will find it. If you begin by looking for evidence that such views are based on ideology and nationalistic sentiments, you will find it. But if race and racial views are strongly correlated with ideology and nationalistic feelings, then these studies - much like the proverbial blind men describing an elephant - may each be highlighting one true component of a collective set of influences. Even studies in which participants deny race influenced their thinking can potentially be explained given the line of research that suggests discomfort with acknowledging the role of race in our lives and thoughts could lead people to falsely deny, or even fail to personally recognize, how race influences them (Gaertner and Dovidio. 1986).

Scholars studying public opinion on a quite disparate set of issues have found that both ideology and racial views guide responses on such matters as welfare (Kinder and Sanders 1996), health care (Henderson and Hillygus 2011), criminal justice (Unnever and Cullen 2007), gun safety measures (Filindra and Kaplan 2016), voter ID laws (Wilson and Brewer 2013), and climate change (Benegal 2018). Here I posit that both race and ideology matter - and that even after controlling for ideology - racial views will influence perspectives on political athletes. 


\section{Methods}

To explore the factors that influence attitudes toward political athletes, I utilize survey data from the Pew Research Center. 5 Their September 2019 national poll asked respondents: "How acceptable, if at all, do you think it is for professional athletes to speak out publicly about political issues?" The question does not specifically direct the respondent to think about one particular aspect of sports and politics, but rather leaves open whether anthem protests, candidate endorsements, or other political acts are top of mind. At the time the question was asked, there were not active anthem protests in the NFL.

A bivariate comparisons shows a strong relationships between responses to political athletes and race, racial views, and ideology. Interestingly, one thing not closely related to views of political athletes is family participation in sports.

\section{Table 1 About Here}

As Table 1 shows, just under 60 percent of white respondents said it was "somewhat acceptable" or "very acceptable" for professional athletes to speak out about political issues. Among African Americans that support rises to over 83 percent. This result is statistically significant $(\mathrm{p}<.001)$.

The poll offers two sets of questions that are well suited for measuring racial resentment. There is a wide battery of research finding that genuine responses to direct questions about racial views can be thwarted by social desirability and other impulses to obfuscate (Krumpal 2013). Here the questions shield the respondent from directly

\footnotetext{
${ }^{5}$ American Trends Panel, Wave 54, September 29, 2019.
} 
expressing any prejudicial feelings by asking, in one case, if they believe "discrimination against racial and ethnic minorities" contributes to economic inequality.

Later in the survey respondents are asked whether current economic conditions are helping or hurting a variety of groups, including "people who are white" and "people who are black." For the purposes of analysis, I create a "white grievance" score by comparing responses to two questions, scored high if respondent believes the economy is helping "blacks" and hurting "whites," and scored low if the respondent believes the economy is helping "whites" and hurting "blacks."

\section{Table 2 About Here}

Table 3 About Here

As Tables 2 and 3 show, both sets of racial responses yield very similar results. Those who do not believe in racism and those who believe the economy hurts "people who are white" more than "people who are black" overwhelmingly disapprove of political athletes. Those who do believe in racism and those who believe the economy hurts "people who are black" overwhelmingly approve of political athletes. In both cases the differences are statistically significant $(\mathrm{p}<.001)$.

\section{Table 4 About Here}

Ideology, to be sure, is also closely related to these responses (Table 4). Among those who consider themselves "very conservative," 63 percent disapprove of political athletes. Among those who call themselves "very liberal," 6 percent disapprove $(\mathrm{p}<.001)$. Indeed, every step from very conservative to very liberal is associated with greater approval of political athletes, with 93 percent approval among the very liberal.

Leaving political influences aside, for a moment, Table 5 shows the relationship between family sports participation and responses to political athletes. In short, there 
really is no relationship. Among those who currently have a child playing sports, 66 percent approved of political athletes. Among those who had a child playing sports but do not now, 65 percent approved. Among those who never had a child playing sports, 72 percent approved. These results suggest the degree to which one's response to sports and politics is not truly about one's relationship to sports, one's history with sports, and the family ties, memories or affiliations wrapped up in sports. In the sports and politics equation, it is the politics that looms larger than the sports.

\section{Table 5 About Here}

Does the picture that emerges here - in which race, racial views, and ideology are all related to feelings about sports and politics - hold up in a multivariate analysis? In addition to race, racial views, ideology and party, I included age and education in the analysis as several researchers have found older Americans and those with lower levels of education are less hospitable to sports and politics (for example, Lacina 2019).

Each variable is coded in the direction of a hypothesized negative relationship. That is race ( $0=$ not white; $1=$ white, $)$, racial views $(-1=$ low white grievance; $1=$ high white grievance), ideology ( $1=$ very liberal, $5=$ very conservative), party ( $1=$ Democrats/Leaners, 2=Republicans/Leaners), age (1=under 30, 4=65 and over), and education (1=graduate degree, $6=$ less than high school degree) are all coded with the higher figure hypothesized to reduce support for political athletes. The dependent variable - again whether the respondent finds athletes who speak out on politics acceptable - is rescaled to 100 points ( $100=$ very acceptable, $O=$ not at all acceptable) for ease of interpretation.

\section{Table 6 About Here}

The results (Table 6) strongly support the premise that there is both a racial and political dynamic at work here. Overall, the profile of an opponent of athlete political 
activism includes those who are older, White, Republican, conservative, lower education, and who hold strong White grievance views. All relationships are statistically significant $(\mathrm{p}<.01)$.

A shift from Democrat to Republican moves respondents 24 points against political athletes. A shift from very liberal to very conservative moves respondents 29 points against political athletes. And the difference between whites with a high level of white grievance and those who are not white and low in white grievance corresponds to a 20 point difference. Standardized coefficients suggest party and ideology are the most consequential influences here, but racial views rank third.

\section{Discussion}

There is, to be sure, no shortage of anger and outrage to be found at the intersection of sports and politics. Chaplin and Montez de Oca $(2019,16)$ quote one respondent speaking of political athletes, "They are corrupting our nation by ruining the patriotic fun of a sports game.” Serazio and Thorson $(2020,158)$ quote research subjects referring to political athletes as "buffoons," and "idiots," and being of "lower intelligence."

Are feelings toward political athletes driven by race or by political beliefs? The results here suggest that may be a distinction without a difference. People with conservative political beliefs are more likely to object to political athletes. People who do not believe racial discrimination exists, or believes white are victims, are more likely to object to political athletes. In both bivariate and multivariate analyses, responses to political athletes are driven both by political belief and by race.

Critics have lamented occasions when athletes have failed to use their prominence to advance political causes or where their silence has bolstered the status 
quo (Andrews 1996). The results here suggest that a fair critic must acknowledge that political activism could come at a cost to athletes of product endorsements (McDonald 1996), public approval (Schmidt, Frederick, Pegoraro, and Spencer 2019; Sanderson, Frederick, and Stocz 2016; Lacina 2019) and even their place on the team (Niven 2020). Even still, it is no small thing to ask an athlete to accept the consequences of political activism that could include exacerbating already existing levels of race-based vitriol (see, for example, Oshiro, Weems, and Singer 2020).

Why, of all issues one could highlight, did Donald Trump castigate NFL players for kneeling during the anthem in a September 2017 appearance in Alabama? At the time there were only a scattered few players engaged in the protest and Colin Kaepernick had been run off from the league. Why did several Republican congressional candidates in 2018 run ads decrying national anthem protesters? An ad from the National Republican Campaign Committee for Representative Jim Hagedorn, for example, depicted soldiers and fire firefighters amidst images of guns, flags, coffins, cemeteries and 9/11. "Land of the free, home of the brave...and they never took a knee," the announcer solemnly said, as each photo, all depicting white men, flashed by. This was juxtaposed with an image of kneeling Colin Kaepernick, the only African American shown in the ad. ${ }^{6}$ The results here help supply context to these political choices. In much the same way talking about standing with police is an effective shorthand for conveying racial sentiments today (see, for example, Drakulich, Wozniak, Hagan, and Johnson 2020), talking about the anthem protests is effectively a shorthand not only for

${ }^{6} \mathrm{https}: / /$ www.youtube.com/watch?time_continue $=15 \& \mathrm{v}=\mathrm{Z} 3 \mathrm{NwFtPy}-$ P4\&feature=emb_logo (last accessed 9/1/2020). 
conservative thought, but for white grievance. It is a means to speak about race without directly speaking about race.

While the centrality of race in sports and politics may be staring us in the face, the media often find a way to call it something other than it is. As Graber and colleagues found (2019), Kaepernick's protest over racial injustice became a matter of patriotism in much media coverage. In a similar vein, a decade earlier Niven (2005) found that when right-wing commentator Rush Limbaugh accused the media of being biased in favor of African American quarterbacks, much of the resulting coverage centered on the playing ability of the quarterbacks rather than engaging with any aspect of the racial dynamics at hand. Failing to treat issues of race as issues of race denies activist athletes a full hearing on their views, but broadly, it perpetuates society's self-serving depiction of sports as a color blind utopia.

The intersection of sports and politics continues to evolve. Tactics are expanding far beyond the gestures, t-shirts, and pre-game moments of protest. We have seen players walking off the court and the field, refusing to play the game, to protest injustice. We have seen players develop plans for mass outreach organizations to encourage voting. But even as the tactics of the politically-involved athlete evolve and expand, the results here offer a warning. Regardless of the tactics or the topic, racial views will drive some Americans to oppose and belittle the athletes' efforts. 


\section{References}

Agyemang, Kwame, John N. Singer, and Joshua DeLorme. "An exploratory study of black male college athletes' perceptions on race and athlete activism." International Review for the Sociology of Sport 45.4 (2010): 419-435.

Andrews, David L. 1996. "The fact(s) of Michael Jordan's blackness: Excavating a floating racial signifier." Sociology of Sport Journal 13 (2): 125-158.

Belson, K. 2019. "NFL Settlement with Kaepernick and Reid is Said to Be Much Less Than \$10 Million." New York Times, March 21.

Benegal, Salil D. "The spillover of race and racial attitudes into public opinion about climate change." Environmental Politics 27.4 (2018): 733-756.

Bondy, S. 2016. “Anonymous NFL GMs call Colin Kaepernick a 'Traitor,' Say They'd Never Sign Him.” New York Daily News, August 31.

Branch, J. 2018. "National Anthem Protests Sidelined by Ambiguity." New York Times January 1.

Bucher, Charles. "Sports are color-blind." Journal of Health, Physical Education, Recreation 28, no. 9 (1957): 21-22.

Chaplin, Kenneth Sean, and Jeffrey Montez de Oca. "Avoiding the issue: University students' reponses to NFL players' national anthem protests." Sociology of Sport Journal 36.1 (2019): 12-21.

Coombs, Danielle Sarver, and David Cassilo. "Athletes and/or activists: LeBron James and Black lives matter." Journal of Sport and Social Issues 41.5 (2017): 425-444.

Cooper, Joseph N., Charles Macaulay, and Saturnino H. Rodriguez. "Race and resistance: A typology of African American sport activism." International Review for the Sociology of Sport 54.2 (2019): 151-181.

Davis, Catasha R., Michael C. Thornton, and Sean Moxley-Kelly. "A Contested Cultural Space: Color-Blind Rhetoric in Discussions of College Football." Communication \& Sport 6.4 (2018): 457-476.

Drakulich, Kevin, Kevin H. Wozniak, John Hagan, and Devon Johnson. "Race and policing in the 2016 presidential election: Black lives matter, the police, and dog whistle politics." Criminology 58, no. 2 (2020): 370-402.

Druckman, James N., Adam J. Howat, and Andrew Rodheim. "The influence of race on attitudes about college athletics." Sport in Society 19.7 (2016): 1020-1039. 
Druckman, James N., Adam J. Howat, and Jacob E. Rothschild. "Political protesting, race, and college athletics: Why diversity among coaches matters." Social Science Quarterly 100.4 (2019): 1009-1022.

Elias, Robert. "The national pastime trade-off: how baseball sells US foreign policy and the American way." The International Journal of the History of Sport 28, no. 17 (2011): 2506-2526.

Filindra, Alexandra, and Noah J. Kaplan. "Racial resentment and whites' gun policy preferences in contemporary America." Political behavior 38.2 (2016): 255-275.

Flaherty, B. 2017. “From Kaepernick Sitting to Trump's Fiery Comments: NFL's Anthem Protests have Spurred Discussion.” Washington Post, September 24.

Frederick, Evan L., Ann Pegoraro, and Jimmy Sanderson. "Divided and united: Perceptions of athlete activism at the ESPYS." Sport in Society 22 (2018): 1919-1936.

Gaertner, Samuel, and John Dovidio. 1986. "The Aversive Form of Racism.” In Prejudice, Discrimination, and Racism, Samuel Gaertner and John Dovidio (eds.). Orlando: Academic Press.

Gorsevski, Ellen W., and Michael L. Butterworth. "Muhammad Ali's fighting words: The paradox of violence in nonviolent rhetoric." Quarterly Journal of Speech 97.1 (2011): $50-73$.

Goudsouzian, Aram. "From Lew Alcindor to Kareem Abdul-Jabbar: Race, Religion, and Representation in Basketball, 1968-1975." Journal of American Studies 51.2 (2017): 437-470.

Goudsouzian, Aram. "Bill Russell and the Basketball Revolution." American Studies 47.3/4 (2006): 61-85.

Graber, Shane M., Ever J. Figueroa, and Krishnan Vasudevan. "Oh, Say, Can You Kneel: A Critical Discourse Analysis of Newspaper Coverage of Colin Kaepernick's Racial Protest." Howard Journal of Communications (2019): 1-17.

Henderson, Michael, and D. Sunshine Hillygus. "The dynamics of health care opinion, 2008-2010: Partisanship, self-interest, and racial resentment." Journal of Health Politics, Policy and Law 36.6 (2011): 945-960.

Intravia, Jonathan, Alex R. Piquero, and Nicole Leeper Piquero. "The racial divide surrounding United States of America national anthem protests in the National Football League." Deviant Behavior 39.8 (2018): 1058-1068.

Intravia, Jonathan, Alex R. Piquero, Nicole Leeper Piquero, and Bryan Byers. "Just do it? An examination of race on attitudes associated with Nike's advertisement featuring Colin Kaepernick." Deviant Behavior (2019): 1-11. 
Johnson, Tyler, Lauren Reinke, Gloria Noble, and Tyler Camarillo. "Shut up and dribble? How popularity, activism, and real-world events shape attitudes towards LeBron James and race." The Social Science Journal (2020): 1-20.

Johnk, Z. 2017. "National Anthem Protests by Black Athletes Have a Long History." New York Times, September 25.

Kinder, Donald, and Lynn M. Sanders. Divided by color: Racial politics and democratic ideals. University of Chicago Press, 1996.

Krumpal, Ivar. "Determinants of social desirability bias in sensitive surveys: a literature review." Quality \& Quantity 47.4 (2013): 2025-2047.

Kusz, Kyle W. "From NASCAR nation to Pat Tillman: Notes on sport and the politics of white cultural nationalism in post-9/11 America." Journal of Sport and Social Issues 31.1 (2007): 77-88.

Lacina, Bethany. "Public opinion and black NFL players after the national anthem protests." Unpublished manuscript (2019).

Linden, Andrew David. "Political Football: Social Movements and the Professional Gridiron in the United States, 1955-1979." Ph.D. dissertation, Pennsylvania State University, (2016).

McDonald, M.G. 1996. "Michael Jordan's Family Values: Marketing, Meaning, and PostReagan America." Sociology of Sport Journal 13(4): 344-365.

Niven, David. "Race, quarterbacks, and the media: Testing the Rush Limbaugh hypothesis." Journal of Black Studies 35, no. 5 (2005): 684-694.

Niven, David. "The effect of economic vulnerability on protest participation in the National Football League." Social Science Quarterly 100.4 (2019): 997-1008.

Niven, David. "Stifling Workplace Activism: The Consequences of Anthem Protests for NFL Players." Social Science Quarterly 101.2 (2020): 641-655.

Oshiro, Kristi F., Anthony J. Weems, and John N. Singer. "Cyber Racism Toward Black Athletes: A Critical Race Analysis of http://TexAgs. com Online Brand Community." Communication \& Sport (2020): 2167479520911888.

Sanderson, J., E. Frederick, and M. Stocz. 2016. "When Athlete Activism Clashes with Group Values: Social Identity Threat Management via Social Media.” Mass Communication and Society 19(3): 301-322. 
Schmidt, S., E. Frederick, A. Pegoraro, and T. Spencer. 2019. "An Analysis of Colin Kaepernick, Megan Rapinoe, and the National Anthem Protests." Communication \& Sport 7(5): 653-677.

Schmittel, A., and J. Sanderson. 2015. "Talking about Trayvon in 140 Characters: Exploring NFL Players' Tweets about the George Zimmerman Verdict." Journal of Sport and Social Issues 39(4): 332-345.

Serazio, Michael, and Emily Thorson. "Weaponized patriotism and racial subtext in Kaepernick's aftermath: The anti-politics of American sports fandom." Television \& New Media 21.2 (2020): 151-168.

Sevi, Barış, Nathan Altman, Cameron G. Ford, and Natalie J. Shook. "To kneel or not to kneel: Right-wing authoritarianism predicts attitudes toward NFL kneeling protests." Current Psychology (2019): 1-8.

Sorek, Tamir, and Robert G. White. "American football and national pride: Racial differences." Social science research 58 (2016): 266-278.

Stratmoen, Evelyn, Tiffany J. Lawless, and Donald A. Saucier. "Taking a knee: Perceptions of NFL player protests during the National Anthem." Personality and Individual Differences 137 (2019): 204-213.

Thorson, Emily A., and Michael Serazio. "Sports fandom and political attitudes." Public Opinion Quarterly 82.2 (2018): 391-403.

Towler, Christopher C., Nyron N. Crawford, and Robert A. Bennett. "Shut Up and Play: Black Athletes, Protest Politics, and Black Political Action." Perspectives on Politics 18.1 (2020): 111-127.

Unnever, James D., and Francis T. Cullen. "Reassessing the racial divide in support for capital punishment: The continuing significance of race." Journal of Research in Crime and Delinquency 44.1 (2007): 124-158.

Wallsten, Kevin, Tatishe M. Nteta, Lauren A. McCarthy, and Melinda R. Tarsi. "Prejudice or principled conservatism? Racial resentment and white opinion toward paying college athletes." Political Research Quarterly 70, no. 1 (2017): 209-222.

Watanabe, Nicholas Masafumi, and George B. Cunningham. "The impact of race relations on NFL attendance: An econometric analysis." Plos one 15.1 (2020): e0226938.

Wilson, David C., and Paul R. Brewer. "The foundations of public opinion on voter ID laws: Political predispositions, racial resentment, and information effects." Public Opinion Quarterly 77.4 (2013): 962-984. 
Table 1. Acceptability of Political Athletes by Respondent Race

\begin{tabular}{|l|l|l|}
\hline & White & $\begin{array}{l}\text { African } \\
\text { American }\end{array}$ \\
\hline $\begin{array}{l}\text { Acceptable } \\
\text { (Very/Somewhat) }\end{array}$ & 38.7 & 11.9 \\
\hline $\begin{array}{l}\text { Not Acceptable } \\
\text { (Not too/Not at all) }\end{array}$ & 61.3 & 88.1 \\
\hline
\end{tabular}

$\mathrm{n}=6738$

$\mathrm{p}<.001$

Table 2. Acceptability of Political Athletes by Racial Grievance

\begin{tabular}{|l|l|l|l|}
\hline & $\begin{array}{l}\text { Economy Disfavors } \\
\text { Whites }\end{array}$ & Neutral & $\begin{array}{l}\text { Economy } \\
\text { Disfavors African } \\
\text { Americans }\end{array}$ \\
\hline $\begin{array}{l}\text { Acceptable } \\
\text { (Very/Somewhat) }\end{array}$ & 36.2 & 54.4 & 85.9 \\
\hline $\begin{array}{l}\text { Not Acceptable } \\
\text { (Not too/Not at all) }\end{array}$ & 63.8 & 45.6 & 14.1 \\
\hline
\end{tabular}

$\mathrm{n}=3311$

$\mathrm{p}<.001$, Chi-Square $=531.6$

Table 3. Acceptability of Political Athletes by Belief in Discrimination

\begin{tabular}{|l|l|l|l|}
\hline & Not at All & Some & A Great Deal \\
\hline $\begin{array}{l}\text { Acceptable } \\
\text { (Very/Somewhat) }\end{array}$ & 32.2 & 60.6 & 85.1 \\
\hline $\begin{array}{l}\text { Not Acceptable } \\
\text { (Not too/Not at all) }\end{array}$ & 67.8 & 39.4 & 14.9 \\
\hline
\end{tabular}

$\mathrm{n}=3344$

$\mathrm{p}<.001$, Chi-Square $=410.2$

Table 4. Acceptability of Political Athletes by Ideology

\begin{tabular}{|l|l|l|l|l|l|}
\hline & $\begin{array}{l}\text { Very } \\
\text { Conservative }\end{array}$ & Conservative & Moderate & Liberal & $\begin{array}{l}\text { Very } \\
\text { Liberal }\end{array}$ \\
\hline $\begin{array}{l}\text { Acceptable } \\
\text { (Very/Somewhat) }\end{array}$ & 34.7 & 36.5 & 69.9 & 89.5 & 93.4 \\
\hline $\begin{array}{l}\text { Not Acceptable } \\
\text { (Not too/Not at } \\
\text { all) }\end{array}$ & 65.3 & 63.5 & 30.1 & 10.5 & 6.6 \\
\hline
\end{tabular}

$\mathrm{n}=3344$

$\mathrm{p}<.001$, Chi-Square 1399.8 
Table 5. Acceptability of Political Athletes by Child's Sports Experience

\begin{tabular}{|l|l|l|l|}
\hline & Child Plays & Child Played & $\begin{array}{l}\text { No Child in } \\
\text { Sports }\end{array}$ \\
\hline $\begin{array}{l}\text { Acceptable } \\
\text { (Very/Somewhat) }\end{array}$ & 68.5 & 66.3 & 71.9 \\
\hline $\begin{array}{l}\text { Not Acceptable } \\
\text { (Not too/Not at all) }\end{array}$ & 31.5 & 33.7 & 28.1 \\
\hline
\end{tabular}

$\mathrm{n}=1696$

$\mathrm{p}>.05$, Chi-Square 3.7

Table 6. Acceptability of Political Athletes

Regression Analysis

\begin{tabular}{|l|l|l|l|}
\hline & Coefficient & Standard Error & $\begin{array}{l}\text { Standardized } \\
\text { Coefficient }\end{array}$ \\
\hline Constant & $132.98^{*}$ & 2.75 & \\
\hline White & $-3.89^{*}$ & 1.27 & -.046 \\
\hline Age & $-3.14^{*}$ & .56 & -.082 \\
\hline Education & $-1.47^{*}$ & .36 & -.059 \\
\hline Party & $-24.55^{*}$ & 1.55 & -.318 \\
\hline Ideology & $-7.27^{*}$ & .670 & -.207 \\
\hline Racial Views & $-8.07^{*}$ & .913 & -.150 \\
\hline Adjusted $\mathrm{r}^{2}=.380$ & \multicolumn{3}{|l|}{} \\
\hline
\end{tabular}

$\mathrm{n}=3208$

${ }^{*} \mathrm{p}<.01$ 